\title{
Pengaruh Pengembangan Karier Terhadap Kinerja Karyawan Di PT. Unibless Indo Multi
}

\author{
${ }^{1}$ Lili Sularmi, ${ }^{2}$ Teul Panda Banjal \\ ${ }^{1}$ Dosen Fakultas Ekonomi Universitas Pamulang \\ ${ }^{2}$ Alumni Universitas Pamulang \\ Email : ${ }^{1}$ lilisularmi.ls81@gmail.com, ${ }^{2}$ teultoni@gmail.com
}

\begin{abstract}
ABSTRAK
Tujuan penelitian ini adalah untuk mengetahui pengaruh pengembangan karier terhadap kinerja karyawan pada PT. Unibless Indo Multi

Metode penelitian dilakukan dengan pendekatan asosiatif metode deskriptif kuantitatif. Teknik sampling yang digunakan adalah teknik sampling jenuh dengan sampel sebanyak 60 responden. Analisis data menggunakan analisis regresi, analisis koefisien korelasi, analisis koefisien determinasi dan uji hipotesis

Hasil penelitian ini diperoleh persamaan regresi $\mathrm{Y}=13,493+0,664 \mathrm{X}$ sementara nilai koefisien korelasi sebesar $\mathrm{r}=0.792$ yang berarti korelasi antara Pengembangan Karier dengan kinerja karyawan berada pada kategori kuat dan signifikan. Sedangkan nilai koefisien determinasi menunjukan bahwa kinerja karyawan dipengaruhi oleh Pengembangan Karier sebesar $62.7 \%$ sisanya sebesar $37.3 \%$ dipengaruhi oleh faktor lain, hasil pengujian hipotesis maka thitung $>$ ttabel yaitu 9,887>1,67 yang artinya bahwa H0 ditolak dan Ha diterima, artinya Pengembangan Karier (X) mempunyai pengaruh yang signifikan terhadap Kinerja Karyawan (Y).
\end{abstract}

Kata Kunci : Pengembangan Karier dan Kinerja Karyawan 


\section{PENDAHULUAN}

Melimpahnya sumber daya manusia yang ada saat ini mengharuskan untuk berpikir secara seksama yaitu bagaimana dapat memanfaatkan sumber daya manusia secara optimal. Agar di masyarakat tersedia sumber daya manusia yang handal diperlukan pendidikan yang berkualitas, penyediaan berbagai fasilitas sosial, lapangan pekerjaan yang memadai. Kelemahan dalam penyediaan berbagai fasilitas tersebut akan menyebabkan keresahan sosial yang akan berdampak kepada keamanan masyarakat. Saat ini kemampuan sumber daya manusia masih rendah baik dilihat dari kemampuan intelektualnya maupun keterampilan teknis yang dimilikinya.

Perusahaan juga harus dapat bersaing dengan keunggulan yang dimilikinya, keunggulan yang dimiliki perusahaan bisa berasal dari faktor material, mesin, sumber daya manusia, modal dan lainnya. Maka perusahaan harus bisa memperhatikan salah satu faktor yang sangat menunjang kegiatan operasional perusahaan yaitu sumber daya manusia.

Manajemen sumber daya manusia merupakan bagian dari manajemen keorganisasian yang berfokus pada sumber daya manusia yaitu atau karyawan yang menjadi pelaksana dan pelaku aktif dari setiap aktifitas perusahaan atau badan usaha. Untuk mencapai tujuan perusahaan diperlukan adanya karyawan yang memiliki kemampuan yang cukup untuk memajukan perusahaan.

Sumber daya manusia adalah aset perusahaan sehingga SDM sangat menentukan tercapai tidaknya tujuan perusahaan.perusahaan harus berusaha untuk mendapatkan dan menempatkan SDM yang kualified pada setiap jabatan.Untuk itu diperlukan adanya seleksi calon tenaga kerja ( I Komang, 2012:70 )

Industri telekomunikasi dan informatika (telematika) dalam negeri mengalami pertumbuhan signifikan setelah penerapan kebijakan tingkat komponen dalam negeri (TKDN) untuk smartphone dan perangkat teknologi informasi $4 \mathrm{G}$.

Di era digital saat ini, di gitalisasi arsip artikel berita surat kabar menjadi sangat penting untuk dilakukan. Digitalisasi perlu dilakukan untuk mempermudah akses perolehan informasi bagi mahasiswa dan masyarakat umum.

Digitisasi (bahasa Inggris: digitizing) merupakan sebuah terminologi untuk menjelaskan proses alih media dari bentuk tercetak, audio, maupun video menjadi bentuk digital. Digitisasi dilakukan untuk membuat arsip dokumen bentuk digital, untuk fungsi fotokopi, dan untuk membuat koleksi perpustakaan digital. Digitisasi memerlukan peralatan seperti komputer, scanner, operator media sumber dan software pendukung. Dokumen tercetak dapat dialihkan ke dalam bentuk digital dengan bantuan program pendukung scanning dokumen seperti Adobe Acrobat dan Omnipage. Dokumen audio dapat dialihkan ke dalam bentuk digital dengan bantuan program pengolah audio seperti CoolEdit dan JetAudio. Dokumen video dapat dialihkan ke dalam bentuk digital dengan bantuan program pengolah video.

Tujuan Digitisasi, tidak lain adalah untuk mendapatkan efisiensi 
dan optimalisasi dalam banyak hal antara lain efisiensi dan optimalisasi tempat penyimpanan, keamanan dari berbagai bentuk bencana, untuk meningkatkan resolusi, gambar dan suara lebih stabil.

Saat ini beberapa bidang kehidupan sedang mengalami proses migrasi ke teknologi digital, dengan tujuan untuk mendapatkan efisiensi dan optimalisasi. Antara lain digitisasi bidang telekomunikasi, bidang penyiaran, data-data pemerintah, dan lain sebagainya.

PT. Unibless Indo Multi, adalah suatu perusahaan yang bergerak di bidang jasa, diantaranya IT Trading, yaitu meliputi IT Hardware (PC, Notebook, Server, Storage, Scanner, Printer), Alat Perkantoran (ATK, Rack Dokumen, Meubelair), Alat Peralatan Pendukung Kearsipan (Rak Arsip, Karton Box, RFID). Penjualan dan Penyewaan Komputer dan Perlengkapannya serta Penjualan dan Penyewaan Mesin fotocopy dan Printer Multifungsi (Brand Kyocera), IT Services meliputi jasa penyimpanan dokumen secara fisik, Document Imaging dan Redrawing (Digitalisasi Dokumen), Data Capture, Record Management, Physical Management, Document
Management / Electronic Filing System Solution (EFS), IT System Integrator, Office Moving Services, Digital Printing Services serta Training di bidang Dokumen dan Manajemen Pengarsipan serta IT Outsourcing yaitu jasa Alih Daya (Outsourcing) Office Staf, dan menyediakan jasa Manajemen dan Konsultasi Dokumen

Pengembangan adalah Implementasi rencana-rencana karier memerlukan pengembangan karier merupakan upaya-upaya pribadi seorang karyawan untuk mencapai suatu rencana karier.kegiatankegiatan ini mungkin didukung departemen personalia,atau tidak tergantung pada departemen.berikut akan dibahas taktik-tatik yang dapat digunakan para karyawan dalam pengembangan karier,dan kemudian dixinci peranan departemen personalia dalam kegiatan-kegiatan tersebut (Handoko 2014 : 131)

Pengembangan karier karyawan pada PT. Unibless Indo Multi cenderung berjalan lambat, pr omosi-promosi jabatan tidak dilakukan dengan baik. Adapun beberapa hambatan pengembangan karier di perusahaan dapat dilihat dari tabel 1di bawah ini :

\section{Tabel 1}

Tahapan Pengembangan Karier PT. Unibless Indo Multi

\begin{tabular}{|c|c|c|c|c|}
\hline No. & Jabatan & $\begin{array}{c}\text { Naik } \\
\text { Jabatan }\end{array}$ & $\begin{array}{c}\text { Realisasi/Jumlah } \\
\text { Karyawan(Orang) }\end{array}$ & Keterangan \\
\hline 1. & Helper & $\begin{array}{c}\text { Periode } 1 \\
\text { Tahun }\end{array}$ & $15 / 60$ & $\begin{array}{c}\text { Dari 60 karyawan hanya 15 karyawan } \\
\text { yang naik menjadi operator scanner }\end{array}$ \\
\hline 2. & $\begin{array}{c}\text { Operator } \\
\text { Scanner }\end{array}$ & $\begin{array}{c}\text { Periode } 1 \\
\text { Tahun }\end{array}$ & $15 / 60$ & $\begin{array}{c}\text { Dari 60 karyawan hanya 20 karyawan } \\
\text { yang naik menjadi entri data }\end{array}$ \\
\hline 3. & Entri Data & $\begin{array}{c}\text { Periode } 1 \\
\text { Tahun }\end{array}$ & $20 / 60$ & $\begin{array}{c}\text { Dari 60 karyawan hanya 9 karyawan } \\
\text { yang naik menjadi leader }\end{array}$ \\
\hline 4. & Leader & $\begin{array}{c}\text { Periode } 1 \\
\text { Tahun }\end{array}$ & $9 / 60$ & \\
\hline 5. & Supervisor & $\begin{array}{c}\text { Periode } 1 \\
\text { Tahun }\end{array}$ & - & \\
\hline
\end{tabular}




\begin{tabular}{|c|c|c|c|c|}
\hline 6. & Manager & $\begin{array}{c}\text { Periode 3 } \\
\text { Tahun }\end{array}$ & - & \\
\hline 7. & Direktur & $\begin{array}{c}\text { Periode 5 } \\
\text { Tahun }\end{array}$ & - & \\
\hline
\end{tabular}

Sumber: HRD PT. Unibless Indo Multi 2019

Dari hasil observasi di atas tampak pengembangan karier karyawan pada PT. Unibless Indo Multi belum sesuai dengan ketentuan yang berlaku seperti halnya dalam SOP kenaikan jabatan dari helper ke operator setiap karyawan membutuhkan waktu kerja selama satu tahun, namun realisasinya dari 60 orang karyawan hanya 15 orang saja yang diangkat menjadi operator. Dilihat dari realisasi atau kenyataan bahwa pengembangan karier masih tergolong lambat seperti halnya ketentuan yang diberlakukan yaitu peningkatan karir setahun waktu kerja masih jauh dari ketentuan yang ada mulai dari karier helper ke operator dan seterusnya, untuk naik tingkatan diperlukan kedisiplinan dan hasil jasa servis yang baik, tetapi setiap tahun yang di tentukan tidak ada karyawan yang berhasil mencapai target yang telah di tentukan, kenaikan jabatan tidak berdasarkan prestasi kerja karyawan, karena perusahaan kurang memberikan kesempatan untuk tumbuh kepada karyawan dan dukungan manajemen yang masih kurang, ini merupakan hambatan bagi pengembangan karir karyawan PT. Unibless Indo Multi

Wilson Bangun (2016:234) berpendapat "Kinerja aitu hasil kerja yang dicapai setiap karyawan sehingga dapat memberikan kontribusi positif terhadap perusahaan.

Adapun beberapa masalah di perusahaan seperti menurunnya kinerja disebabkan beban kerja yang tinggi, pekerjaan yang tidak sesuai dengan yang diinginkan, kurangnya sosialisasi/ kerja sama antar rekan kerja dan kurang nya kesempatan promosi menjadi salah satu faktor yang menjadikan karyawan kurang puas dalam bekerja, berikut beberapa observasi dilihat dari tabel 2 dibawah ini :

\section{Tabel 2}

Penilaian Kinerja PT. Unibless Indo Multi Periode 2013-2018

\begin{tabular}{|c|c|c|c|c|}
\hline No. & Indikator & $\mathbf{2 0 1 7}$ & $\mathbf{2 0 1 8}$ & Keterangan \\
\hline 1. & $\begin{array}{c}\text { Work Egagement } \\
\text { (Keterikatan Kerja) }\end{array}$ & $77 \%$ & $77 \%$ & $\begin{array}{c}\text { Ketertrikatan kerja tahun 2017 } \\
\text { sama dengan 2018 }\end{array}$ \\
\hline 2. & $\begin{array}{c}\text { Leadership Quality } \\
\text { (Kualitas/Mutu Pimpinan) }\end{array}$ & $71 \%$ & $73 \%$ & $\begin{array}{c}\text { Kualitas / mutu pimpinan pada } \\
\text { tahun 2017 ke 2018 } \\
\text { meningkat }\end{array}$ \\
\hline 3. & $\begin{array}{c}\text { Job Demans } \\
\text { (Tuntutan Tugas) }\end{array}$ & $43 \%$ & $42 \%$ & $\begin{array}{c}\text { Tuntutan tugas menurun dari } \\
\text { tahun 2017 ke tahun 2018 }\end{array}$ \\
\hline 5. & $\begin{array}{c}\text { Social Support } \\
\text { (Hubungan Sosial/kerja } \\
\text { sama) }\end{array}$ & $76 \%$ & $70 \%$ & $\begin{array}{c}\text { Hubungan sosial/kerja sama } \\
\text { pada tahun 2017 ke 2018 } \\
\text { menurun }\end{array}$ \\
\hline & $\begin{array}{c}\text { Job Satisfaction } \\
\text { (Kepuasan Kerja) }\end{array}$ & $72 \%$ & $71 \%$ & $\begin{array}{c}\text { Kepuasan kerja pada tahun 2017 } \\
\text { ke 2018 menurun }\end{array}$ \\
\hline Rata-Rata & 67,8 & $66,6 \%$ & Rata-Rata menurun \\
\hline
\end{tabular}

Sumber: HRD PT. Unibless Indo Multi, 2019 
Dari hasil observasi di atas tampak tingkat penilaian kerja karyawan PT.Unibless Indo Multi mengalami penurunan dari tahun ke tahun disebabkan karena kurangnya keinginan karyawan untuk berkembang, karena tidak adanya dorongan dari pimpinan untuk mengembangkan karier, dari skor $67,8 \%$ pada tahun 2017 menjadi 66,6 $\%$ pada tahun 2018. Pengambilan skor penilaian kinerja meliputi indikator Work Egagement (keterikatan kerja), Leadership Quality (kualitas/mutu pimpinan), Job Demans (tuntutan tugas), Social Support (hubungan sosial), dan Job Satisfaction (kepuasan kerja).

Berdasarkan data di atas dapat dilihat bahwa kinerja karyawan belum maksimal dimana belum sesuai dengan standar penilaian kinerja yang berlaku yaitu setiap item penilaian harus memenuhi skor $80 \%$, dari indikator jumlah pekerjaan, yang masuk kedalam Work Egagement (keterikatan kerja), masih memiliki skor di bawah skor ideal yaitu $80 \%$, serta kemampuan bekerjasama yang masuk kedalam penilaian Social Support (hubungan sosial) masih di bawah standar.

Dari hasil pengamatan berupa observasi pendahuluan, penulis menemukan banyak permasalahan terkait pengembangan karier yang berimbas kepada kinerja karyawan yang menurun maka penulis mengambil kesimpulan terdapat fenomena yang harus di teliti yang berkaitan dengan permasalahan tersebut.

\section{METODE PENELITIAN}

Penelitian ini dilaksanakan di PT. Unibless Indo Multi. Jalan Rawa bambu raya no.88 pasar minggu, Jakarta selatan RT.13/RW.5 Ps. Minggu, Kota jakarta selatan,12520 Tlp.02178844339. Jenis penelitian yang digunakan adalah dengan menggunakan metode penelitian kuantitatif, teknik pengambilan sampel yang digunakan adalah teknik sample jenuh berjumlah 60 dari seluruh populasi. Pengujian data digunakan uji instrumen, uji regresi, uji koefisien determinasi dan uji hipotesis dengan uji $\mathrm{t}$ dan uji $\mathrm{F}$. Menggunakan software SPSS Versi 24

\section{HASIL PENELITIAN DAN PEMBAHASAN}

\section{Persamaan Regresi Linear Sederhana}

Dari hasil pengumpulan kuesioner sebanyak 60 responden dengan kuesioner Pengembangan Karier (X) dan Kinerja Karyawan (Y) sebanyak 10 pernyataan dan diperoleh data sebagai berikut :

Diketahui:

$$
\begin{aligned}
\mathrm{b} & =\frac{\mathrm{N} \sum \mathrm{XY}-\sum X \cdot \sum Y}{\mathrm{~N} \sum \mathrm{X}^{2}-\left(\sum X\right)^{2}} \\
b & =\frac{59250}{89180} \\
b & =0.664 \\
a & =\frac{\sum Y-b \sum X}{n} \\
a & =\frac{2331-1520,56}{60} \\
a & =13,493
\end{aligned}
$$

Dengan demikian dapat diperoleh angka persamaan berdasarkan dari output coefficients $\mathrm{Y}=13,493+0,664 \mathrm{X}$ artinya bahwa perubahan $\mathrm{Y}$ searah dengan perubahan $X$. Jadi nilai $Y$ akan meningkat jika $X$ meningkat, sebaliknya nilai $\mathrm{Y}$ akan menurun 
jika X menurun. Jadi dapat disimpulkan bahwa Pengembangan Karier berpengaruh positif terhadap kinerja karyawan pada PT Unibless Indo Multi artinya jika Pengembangan Karier yang dimiliki oleh karyawan sesuai standar perusahaan maka akan meningkatkan kinerja karyawan, begitu pula sebaliknya. Koefisien regresi $X=0,664$, maka skor variabel $\mathrm{Y}$ akan bertambah 1 satuan dengan asumsi konstanta 13,493 satuan.

\section{Korelasi Product Moment}

Peneliti gunakan untuk mengetahui hubungan antara variabel x (Pengembangan Karier) dengan variabel y (kinerja karyawan), peneliti menggunakan rumus korelasi product moment sebagai berikut :

Diketahui:

$$
r=\frac{n\left(\sum X Y\right)-\sum X \sum Y}{\sqrt{n \sum X^{2}-\left(\sum X\right)^{2}}\left[n \sum Y^{2}-\left(\sum Y\right)^{2}\right]}
$$

$$
\begin{aligned}
& r x y=\frac{(60.89954)-(2290) \cdot(2331}{\sqrt{(60.88888)-(2290)^{2} \cdot \sqrt{ }(60.91605)-(2331)^{2}}} \\
& =\underline{59250} \\
& 74810,606 \\
& =\mathbf{0 . 7 9 2}
\end{aligned}
$$

Berdasarkan hasil analisis dengan menggunakan rumus koefisien korelasi product moment yang didapat yaitu 0.792 yang berarti tingkat pengaruh antara Pengembangan Karier kerja terhadap kinerja karyawan yaitu di tingkat kuat.

\section{Koefisien Determinasi}

KD (koefisien determinasi)

$$
\begin{aligned}
& =r^{2} \times 100 \% \\
& =(0.792)^{2} \times 100 \%
\end{aligned}
$$

$$
=62.7 \%
$$

Hal ini membuktikan bahwa besarnya Pengaruh Pengembangan Karier terhadap Kinerja Karyawan sebesar $62.7 \%$ dan sisanya sebesar $37.3 \%$ dipengaruhi beberapa faktor lain.

\section{Uji Signifikasi}

Berdasarkan

hasil perhitungan di atas, maka peneliti melakukan pengujian hipotesa dengan cara membandingkan nilai $t_{\text {tabel }}$ dengan $t_{\text {hitung. Nilai }} t_{\text {tabel }}$ ditentukan berdasarkan tingkat signifikan $(\alpha)$ yang digunakan dan derajat kebebasan $(\mathrm{df}=\mathrm{n}-2)$ yang besarnya tergantung dari jumlah sampel (n). Taraf nyata yang penulis gunakan sebesar 0.05 $(5 \%)$.

Rumus $t$ hitung adalah sebagai berikut :

$$
\begin{aligned}
t_{\text {hitung }} & =\frac{r \sqrt{\mathrm{n}-2}}{\sqrt{1-\mathrm{r}^{2}}} \\
\mathrm{t} & =\frac{6.03}{0.61} \\
\mathrm{t} & =9,887016393 \approx 9,887
\end{aligned}
$$

Pengambilan keputusan menggunakan angka pembanding $\mathrm{t}_{\text {tabel dengan kriteria sebagai }}$ berikut:

Sehingga berdasarkan hasil pengujian rumus di atas maka $t_{\text {hit }}>$ $\mathrm{t}_{\text {tab }}$ yaitu 9,887>1,67 yang artinya bahwa $\mathrm{H}_{0}$ ditolak dan $\mathrm{H}_{\mathrm{a}}$ diterima, artinya Pengembangan Karier (X) mempunyai pengaruh yang signifikan terhadap Kinerja Karyawan (Y).

Dari hasil pengolahan data diperoleh persamaan regresi $Y=13,493+0,664 X$ sementara nilai koefisien korelasi sebesar $\mathbf{r}=\mathbf{0 . 7 9 2}$ yang berarti korelasi antara Pengembangan Karier dengan 
kinerja karyawan berada pada kategori kuat dan signifikan. Sedangkan nilai koefisien determinasi menunjukan bahwa kinerja karyawan dipengaruhi oleh Pengembangan Karier sebesar $\mathbf{6 2 . 7 \%}$ sisanya sebesar $37.3 \%$ dipengaruhi oleh faktor lain.

\section{KESIMPULAN DAN SARAN}

\section{A. Kesimpulan}

Berdasarkan pembahasan bab sebelumnya serta ditunjang dengan hasil penelitian yang dilakukan, maka penulis menarik kesimpulan serta saran - saran yang diharapkan dapat berguna bagi PT Unibless Indo Multi

1. Pelaksanaan pengembangan karier yang diterapkan pada PT Unibless Indo Multi sudah cukup baik, hal ini dibuktikan berdasarkan yang menjawab sangat setuju (SS) sebesar $16,3 \%$ dan setuju (S) sebesar $53,3 \% \quad(\mathrm{SS}+\mathrm{S}=16,3$ $\%+53,3 \%=69,6 \%)$, dan pada indikator kesetiaan organisasional, pada pernyataan nomor 6 sebesar 13 responden menjawab sangat setuju maka karyawan berkeinginan mengabdikan diri bagi perusahaan hingga usia pensiun tiba

2. Kinerja karyawan pada PT Unibless Indo Multi sudah cukup baik hal ini dibuktikan berdasarkan yang menjawab sangat setuju (SS) sebesar $17,8 \%$ dan setuju (S) sebesar $55,3 \%(\mathrm{SS}+\mathrm{S}=17,8 \%+55,3 \%=$ $73,1 \%$ ), dan untuk indikator kemampuan kerjasama, pada pernyataan nomor 10 terbesar 17 responden menjawab sangat setuju, maka kemampuan kerjasama antar karyawan yang terus meningkat menandakan bahwa kinerja karyawan semakin baik.

3. Dari hasil pengolahan data diperoleh persamaan regresi $\mathrm{Y}=13,493+0,664 \mathrm{X}$ sementara nilai koefisien korelasi sebesar $\mathrm{r}=0.792$ yang berarti korelasi antara Pengembangan Karier dengan kinerja karyawan berada pada kategori kuat dan signifikan. Sedangkan nilai koefisien determinasi menunjukan bahwa kinerja karyawan dipengaruhi oleh Pengembangan Karier sebesar $62.7 \%$ sisanya sebesar $37.3 \%$ dipengaruhi oleh faktor lain, hasil pengujian hipotesis maka $t_{\text {hitung }}>t_{\text {tabel }}$ yaitu $12.329>2,002$ yang artinya bahwa $\mathrm{HO}$ ditolak dan Ha diterima, artinya Pengembangan Karier (X) mempunyai pengaruh yang signifikan terhadap Kinerja Karyawan (Y).

\section{B. Saran}

Terkait dengan masih terdapat responden yang memilih tidak setuju dan sangat tidak setuju, maka penulis memberikan saran sebagai berikut:

1. Disarankan kepada pimpinan untuk mendorong karyawannya menjadi terkenal oleh orangorang yang memutuskan (pimpinan langsung, SPV/Manager/ Direktur) promosi, transfer dan kesempatan-kesempatan karier lainnya

2. Disarankan perusahaan menyediakan mentor/orang yang menawarkan bimbingan 
karier informal guna pengembangan karier karyawan

3. Disarankan para karyawan memperhatikan ketepatan waktu agar menjadi prioritas dalam menjalankan pekerjaan

4. Disarankan perusahaan memberikan masukan tentang cara karyawan berkreativitas dalam menyelesaikan pekerjaannya.

\section{DAFTAR PUSTAKA}

Bangun, Wilson. 2012. Manajemen Sumber Daya Manusia. Jakarta: Erlangga.

Burhanuddin.2016.Manajemen SDM untuk Perusahaan. Jakarta: PT Raja Grafindo

Dessler, Gary. 2015. Manajemen Sumber Daya Manusia. Jakarta: Salemba. Empat.

Fahmi, Irham. 2016. Manajemen Sumber Daya Manusia. Yogyakarta: Alfabeta.

Fattah, Hussein. 2015. Kepuasan Kerja dan Kinerja Pegawai. Yogyakarta:Elmatera (Anggota IKAPI).

Hamali, Arif Yusuf. 2018. Pemahaman Sumber Daya Manusia. Yogyakarta: CAPS

Handoko, T. Hani. 2014. Manajemen Personalia dan Sumber Daya Manusia. Yogyakarta: BPFE.

Hasibuan, Malayu. 2017. Manajemen Sumber Daya Manusia. Yogyakarta: Bumi Aksara.

I Komang dkk. 2012. Manajemen Sumber Daya Manusia. Yogyakarta: Graha ilmu

Kartono, Kartini, 2015. Pemimpin dan Kepemimpinan. Jakarta : PT. Raja.
Ma'ruf. Muhammad 2016. Manajemen Komunikasi Periklanan. Yogyakarta: Aswaja Pressindo

Mangkunegara, Anwar Prabu. 2017. Manajemen Sumber Daya Manusia Perusahaan. Bandung: PT Remaja Rosdakarya

Miller, Leroy Roger dan Meiners, Roger E. 2015.TeoriMikroekonomi Intermediate.Jakarta : PT Raja GrafindoPersada

Nawawi. H. Hadari. 2016. Manajemen Sumber Daya Manusia. Cetakan Ketujuh. Yogyakarta : Gadjah Mada University Press

Noe, Raymond A., Hollenbeck, John R., Gerhart, Barry, Wright, Patrick M., 2014. Manajemen SumberDaya Manusia : Mencapai Keunggulan Bersaing, Edisi 6 Buku 1, Alih Bahasa : David Wijaya, Jakarta: Salemba Empat

Payaman J. Simanjuntak. 2005. Manajemen Evaluasi Kinerja. Edisi 3. Jakarta. Fakutas UI Rialmi, Z., \& Morsen, M. (2020). Pengaruh Komunikasi Terhadap Kinerja Karyawan PT Utama Metal Abadi. JENIUS, 3(2), 221-227.

Rialmi, Z. (2017). Pengaruh Keadilan Prosedural Yang Diterapkan Kepemimpinan Pegawai Dan Kepuasan Kerja Pegawai Terhadap Kinerja Dari Pegawai BPBD Provinsi Riau. Jurnal Mandiri: Ilmu Pengetahuan, Seni, dan Teknologi, 1(2), 353374.

Rivai, Vithazal Dan Sagala, Ella Juavani.2013. Sumber Daya 
Manusia Untuk Perusahaan Dari Teori Ke Praktik. Jakarta: PT Grafindo

Robbins, P. Stephen, Mary Coulter.2014. Management. Twelfth Edition. United States: Pearson Education Limited

Safroni, Ladzi. 2012. Manajemen dan Reformasi Pelayanan Publik dalam Konteks Birokrasi Indonesia, Surabaya: Aditya Media Publishing.

Samsudin, Sadili. 2010. Manajemen Sumber Daya Manusia. Bandung : Pustaka Setia.

Siagian, 2018, Manajemen Sumber Daya Manusia, Jakarta, PT. Elek Media Kompetindo.

Sinambela Poltak, 2016. Manajemen

Sumber Daya Manusia, Jakarta

: PT Bumi Aksara

Sudaryono,2014. "Pengantar Bisnis, Teori dan Contoh Kasus." Yogyakarta :Andi

Sudjana, Nana dan Ibrahim.2016.Penelitian Dan Penilaian Pendidikan, Bandung : Sinar Baru Algensindo

Sugiyono, 2016. Metode Penelitian

Kuantitatif, Kualitatif dan R\&D, Jakarta: Alfabeta,

Sunarsi, D. (2018). Pengaruh Gaya Kepemimpinan, Motivasi Dan Disiplin Kerja Terhadap Kinerja Pendidik Yayasan Marvin. Inovasi, 5(1), 1-18.

Suherman. 2012.Kamus Besar

Bahasa Indonesia. Jakarta: Pustaka Pelajar
Sunyoto. Danang S. 2015. Manajemen Sumber Daya Manusia Teori dan Aplikasi. Bandung: ALFABETA.

Tampubolon, Manahan. 2017.Perilaku Organisasi. Jakarta: Ghalia Indonesia

Terry, George 2016. Dasar-Dasar Manajemen. Cetakan kesebelas. PT Bumi Aksara: Jakarta

Thoha, Miftah. 2013. Perilaku Organisasi : Konsep Dasar dan Aplikasinya. Raja Grafindo Persada:.Jakarta

Tohardi, 2015, Pemahaman Praktis Manajemen Sumber Daya Manusia,. Universitas Tanjung Pura, Bandung: Mandar Maju.

Triyono, Ayon. 2012. Paradigma Baru Manajemen Sumber Daya Manusia. Jogjakarta: Oryza

Veithzal Rivai Zainal, Mansyur Ramly, Thoby Mutis, Willy Arafah. 2013. Manajemen Sumber Daya Manusia untuk Perusahaan : dari Teori ke Praktik, Edisi Ketiga, Jakarta: Raja Grafindo Persada

Widodo. Suparno Eko. Manajemen Pengembangan Sumber Daya Manusia. Yogyakarta: Pustaka Pelajar

Wibowo. 2014. Manajemen Kinerja. Edisi keenpat, Jakarta: Rajawali Pers

Wirawan. 2015. Evaluasi Kinerja Sumber Daya Manusia Teori Aplikasi dan Penelitian. Jakarta: Salemba Empat. 